\title{
Investigation of the photochemical decomposition of nitrate, hydrogen peroxide, and formaldehyde in artificial snow
}

\author{
Hans-Werner Jacobi*, Thompson Annor, Emmanuel Quansah \\ Alfred Wegener Institute for Polar and Marine Research, Am Handelshafen 12, 27570 Bremerhaven, Germany \\ Received 19 July 2005; received in revised form 22 August 2005; accepted 1 September 2005 \\ Available online 7 October 2005
}

\begin{abstract}
Species like nitrate $\left(\mathrm{NO}_{3}{ }^{-}\right)$, hydrogen peroxide $\left(\mathrm{H}_{2} \mathrm{O}_{2}\right)$, and formaldehyde $(\mathrm{HCHO})$ are ubiquitous trace compounds in snow. Photochemical reactions of these compounds in the snow can have important implications for the composition of the atmospheric boundary layer in snow-covered regions and for the interpretation of concentration profiles in snow and ice regarding the composition of the past atmosphere. Therefore, we performed laboratory experiments to investigate such reactions in artificially produced snow samples. Artificial snow samples allow to execute experiments under defined and reproducible conditions and to investigate single reactions. All reactions were carried out under comparable experimental conditions and indicated that the photolysis of $\mathrm{H}_{2} \mathrm{O}_{2}$ and $\mathrm{NO}_{3}{ }^{-}$occurred equally fast, while the photolysis of $\mathrm{HCHO}$ was considerably slower. Moreover, the photolysis of $\mathrm{HCHO}$ was only observed if initial concentrations were much higher than found in natural snow samples. These results indicate that the $\mathrm{H}_{2} \mathrm{O}_{2}$ and $\mathrm{NO}_{3}{ }^{-}$reactions are possibly equally important in natural snow covers regarding the formation of $\mathrm{OH}$ radicals, while the photolysis of $\mathrm{HCHO}$ is probably negligible. Nitrite $\left(\mathrm{NO}_{2}{ }^{-}\right)$was observed as one of the products of the $\mathrm{NO}_{3}{ }^{-}$photolysis; however, it was itself photolyzed at a higher rate than $\mathrm{NO}_{3}{ }^{-}$. After a certain photolysis period $(\geq 8 \mathrm{~h})$ the $\mathrm{NO}_{3}{ }^{-}$and $\mathrm{NO}_{2}{ }^{-}$concentrations in the snow remained constant at a level of $10 \%$ of the initial nitrogen content. This is probably due to a recycling of the anions from nitrogen oxides in the gas phase of the reaction cells indicating that the chemical reactions occur in or near the surface layer of the snow crystals.
\end{abstract}

(C) 2005 Elsevier B.V. All rights reserved.

Keywords: Photochemical reactions; Snow; Nitrate; Hydrogen peroxide; Formaldehyde

\section{Introduction}

The chemical transformation of many compounds in the atmosphere is initiated and driven by photochemical reactions. Such reactions occurring in the atmospheric gas and liquid phases have extensively been studied (e.g. [1]). Recently, photochemical reactions in the tropospheric ice phase also attracted a lot of interest. Among these are photochemical reactions taking place in the upper layers of the natural snow covers in polar and alpine regions [2]. Because of their ubiquity in the troposphere and their high water solubility, species like nitric acid $\left(\mathrm{HNO}_{3}\right)$, hydrogen peroxide $\left(\mathrm{H}_{2} \mathrm{O}_{2}\right)$, and formaldehyde (HCHO) are common trace compounds in natural snow samples even in remote polar regions [3]. It can be expected that photochemical reactions in snow take place, since these and further organic compounds present in the snow [4,5] can absorb

\footnotetext{
* Corresponding author. Tel.: +49 4714831 1493; fax: +49 47148311425.

E-mail address: hwjacobi@awi-bremerhaven.de (H.-W. Jacobi).
}

solar radiation, which can penetrate into deeper layers (several tens of centimeters) of the snow [6,7]. Indeed, several field and laboratory studies have indicated that a variety of photochemical processes can occur in natural surface snow under the influence of solar radiation [5,8-25]. For example, the photolysis of nitrate $\left(\mathrm{NO}_{3}{ }^{-}\right)$has been identified as one of the key reactions. Therefore, it has been the goal of several laboratory experiments to investigate the reaction mechanism and the reaction products at temperatures typical for natural snow covers [16-20]. More recently, the photolysis reactions of $\mathrm{H}_{2} \mathrm{O}_{2}$ and $\mathrm{HCHO}$ have been the subject of laboratory studies $[21,25]$. Nevertheless, reliable information about the photochemical reaction mechanism in surface snow is still missing. For example, several authors have proposed that in addition to or initiated by the $\mathrm{NO}_{3}{ }^{-}$photolysis organic compounds present in the snow are transformed into highly reactive organic compounds like formaldehyde ( $\mathrm{HCHO})$ or acetone $[2,5,15]$.

The photochemical processes in snow have two important implications. First, they affect the composition of the atmospheric boundary layer in snow-covered areas due to the release 
of photochemically produced compounds like nitrogen oxides $\left(\mathrm{NO}_{x}\right)$. For example, under stable atmospheric conditions, $\mathrm{NO}_{x}$ mixing ratios can reach values in the order of several hundreds of parts per trillion by volume ( $\mathrm{ppt} \mathrm{V}$ ) even in remote polar regions $[13,14]$. Such high levels of $\mathrm{NO}_{x}$ influence the atmospheric oxidation capacity due to their role in the formation of hydroxl radicals and ozone. Second, the photochemical processing can alter the concentrations of the trace compounds in the snow after deposition. This can have a large impact on the interpretation of the concentration profiles in the snow and in firn and ice cores. Such profiles can be utilized to reconstruct concentrations of the compounds in the paleo-atmosphere if so-called transfer functions are known, which relate snow concentrations to atmospheric concentrations [3]. Transfer functions for $\mathrm{NO}_{3}{ }^{-}, \mathrm{H}_{2} \mathrm{O}_{2}$, and $\mathrm{HCHO}$ would be of great importance since these compounds can potentially be used to determine the role of reactive nitrogen species and the oxidation of methane in the atmosphere in the past (e.g. [26]).

Here, we present laboratory experiments concerning the photochemical transformation of $\mathrm{NO}_{3}{ }^{-}, \mathrm{H}_{2} \mathrm{O}_{2}$, and $\mathrm{HCHO}$ in snow, since in most of the previous laboratory studies ice samples rather than snow samples were used. Our experiments were performed using artificially produced snow samples in order to control initial conditions and prevent side reactions. All experiments were performed under equal experimental conditions to obtain results, which are comparable at least for the applied experimental conditions. The applicability and the importance of the observed reactions for the photochemistry occurring in natural snow are discussed.

\section{Experimental methods}

Solutions for the generation of artificial snow were prepared from Milli-Q water (conductivity larger than $18 \mathrm{M} \Omega$ ) by adding either 30\% $\mathrm{H}_{2} \mathrm{O}_{2}$ (Merck, Darmstadt, Germany), 37\% HCHO (Merck, Darmstadt, Germany), or sodium nitrate (Merck, Darmstadt, Germany). All chemicals were used without further purification. Two liters of solutions with initial concentrations of $\sim 9 \times 10^{-6} \mathrm{M} \mathrm{NO}_{3}^{-}, \sim 1 \times 10^{-2} \mathrm{M}$ and $\sim 2 \times 10^{-5} \mathrm{M} \mathrm{H}_{2} \mathrm{O}_{2}$, or $\sim 6 \times 10^{-3} \mathrm{M}$ and $\sim 3 \times 10^{-6} \mathrm{M}$ HCHO were prepared. The preparation of the solutions with the low initial concentrations involved an additional dilution step. The final solutions were transferred into a stainless steel tank, which was pressurized with ambient air to $2-3 \times 10^{5} \mathrm{~Pa}$. Applying this pressure, the liquid was forced through a $1 \mathrm{~mm}$ hollow cone brass nozzle producing a fine spray, which was collected in a Styrofoam container filled with liquid nitrogen. The produced chunks of ice were transferred into a walk-in cold room at $T=-20 \pm 3{ }^{\circ} \mathrm{C}$, where the equipment for the further handling of the ice and snow was stored before using. First, the ice chunks were collected on a piece of aluminum foil. Small portions of the ice were ground with an electric mill and passed through a stainless steel test sieve (Retsch, Haan, Germany) with a mesh size of $0.5 \mathrm{~mm}$. Afterwards, the snow was stored in $1 \mathrm{~L}$ Schott bottles covered with aluminum foil and sealed with traps filled with Hopcalite (Aero-Laser, Garmisch-Partenkirchen, Germany) to allow further degassing of nitrogen and to prevent the condensation of

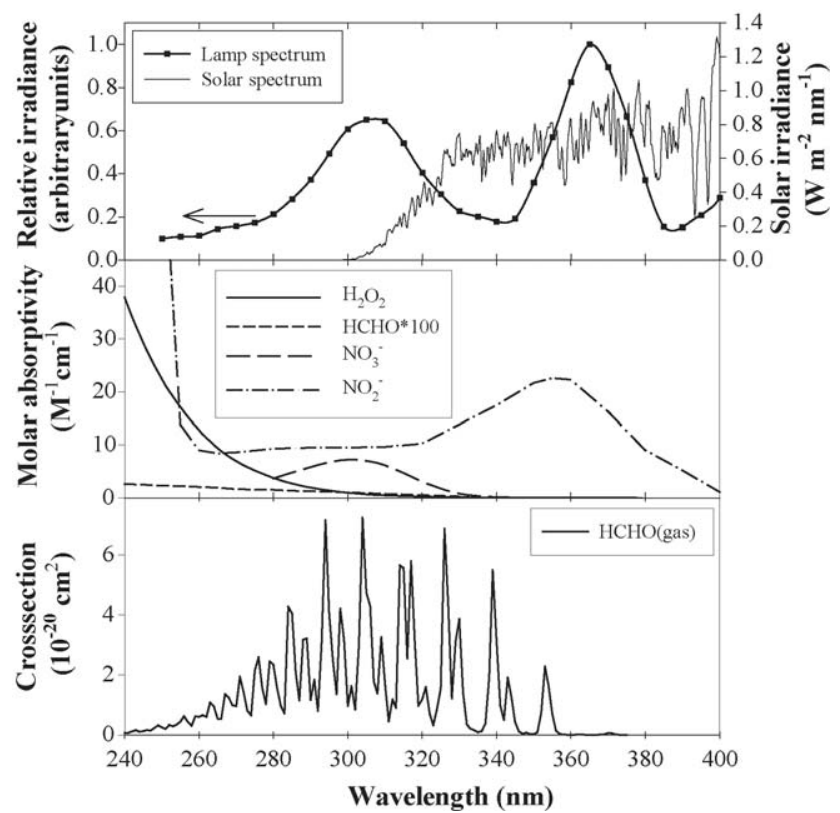

Fig. 1. Comparison of the lamp emission with the solar irradiance measured in Antarctica and with absorption spectra of the investigated compounds. (Top) emission spectrum of the mercury lamp measured behind the water filter with a grating monochromator (77250, Oriel) and a radiometer (IL1700, International Light) connected to a calibrated light sensor (SED400, International Light) and a solar spectrum measured at the German station Neumayer $\left(70^{\circ} 39^{\prime} \mathrm{S}, 08^{\circ} 15^{\prime} \mathrm{W}\right)$ between 12:36 and 12:47 UTC on December 12, 2003 [50]. (Middle) absorption spectra in aqueous solution of $\mathrm{H}_{2} \mathrm{O}_{2}$ at $1{ }^{\circ} \mathrm{C}$ [21], $\mathrm{HCHO}$ measured at $20^{\circ} \mathrm{C}$ (more than 99\% present in the gem-diol form [38], the absorption coefficients are multiplied by 100 ), $\mathrm{NO}_{3}{ }^{-}$at $5{ }^{\circ} \mathrm{C}$ [20], and $\mathrm{NO}_{2}{ }^{-}$at room temperature [51]. (Bottom) absorption spectrum of $\mathrm{HCHO}$ in the gas phase at $25^{\circ} \mathrm{C}$ [52].

impurities on the snow. Newly prepared snow was stored at least overnight before using for the experiments to ensure that the nitrogen was completely removed.

Details of the experimental set-up for the photolysis experiments are described by Jacobi et al. [25]. The samples were irradiated using a $1000 \mathrm{~W}$ Mercury-arc lamp (Oriel Instruments, Stratford, CT) installed in the walk-in cold room. The emission intensity was regulated by the output of the lamp's power supply, which was set to $460 \mathrm{~W}$. A water filter was used to absorb the infrared radiation. The transmittance of the water filter was higher than $80 \%$ between 250 and $700 \mathrm{~nm}$. The emission spectrum measured behind the water filter is shown in Fig. 1. The snow samples (7-9 g) were loosely filled into 1-cm-long Teflon cells with a volume of $32 \mathrm{~cm}^{3}$. During the experiments the cells were entirely illuminated by the light beam. Water filter and cells were equipped with quartz windows (Suprasil, Heraeus, Hanau, Germany).

The concentrations of the trace compounds in the snow were determined before and after each experiment. When filling the cell for a new experiment, a sample of the same batch of snow was kept in an airtight bottle. After the experiment the snow was completely removed from the cell and filled into an airtight bottle. The bottles were stored in the dark at $-20^{\circ} \mathrm{C}$ and the samples were melted before analysis.

Concentrations of $\mathrm{H}_{2} \mathrm{O}_{2}$ and $\mathrm{HCHO}$ in the melted samples were determined by multiple titrations with potassium 
permanganate solution $\left(\mathrm{H}_{2} \mathrm{O}_{2}\right)$ or by iodometric titration ( $\mathrm{HCHO})$. The detection limits and the errors of the titration methods were $1 \times 10^{-4} \mathrm{M}$ for $\mathrm{H}_{2} \mathrm{O}_{2}$ and $4 \times 10^{-4} \mathrm{M}$ for $\mathrm{HCHO}$ representing in each case the addition of a single droplet of the titrant. Lower concentrations were determined with commercial analyzers using fluorometric methods (AL2001CL and AL4001, Aero-Laser, Garmisch-Partenkirchen, Germany). Both instruments have previously been described in detail [27,28]. The instruments are normally used for gas phase measurements. However, they can be switched into the liquid mode to introduce liquid samples directly into the instruments. The analyzers were calibrated at least twice daily using diluted standard solutions and Milli-Q water. Initial concentrations of the standard solutions were also obtained by the titration methods. The limits of detection calculated from three times the standard deviation of the signal for Milli-Q water were $6 \times 10^{-8} \mathrm{M}$ for $\mathrm{H}_{2} \mathrm{O}_{2}$ and $5 \times 10^{-8} \mathrm{M}$ for $\mathrm{HCHO}$, while the overall error in the $\mu \mathrm{M}$ range was in the order of $3 \%$.

An ion chromatography system, normally operated to analyze natural snow samples from both polar regions [29], was used to perform the anion $\left(\mathrm{NO}_{3}{ }^{-}\right.$and $\left.\mathrm{NO}_{2}{ }^{-}\right)$analysis in the artificial snow samples. The system was calibrated with a range of standard solutions and Milli-Q water before and after the analysis of the samples. The overall error for both anions was on the order of $5 \%$.

\section{Results}

Experiments with four different batches of artificial snow were performed in the case of $\mathrm{H}_{2} \mathrm{O}_{2}$. In all experiments a decrease of the $\mathrm{H}_{2} \mathrm{O}_{2}$ concentrations with increasing duration of the irradiation was observed. The decomposition can be described by a first-order rate law in agreement with previous experiments [25]:

$\frac{\mathrm{d}[c]}{\mathrm{d} t}=-k_{1 \mathrm{st}}[c]$

$\ln \left(\frac{[c]}{[c]_{0}}\right)=-k_{1 \mathrm{st}} t$

The first-order rate constant $k_{1 \text { st }}$ corresponds to the experimental photolysis rate $j_{\text {exp }}$. Fig. 2 shows a plot of the logarithm of the relative concentrations of $\left[\mathrm{H}_{2} \mathrm{O}_{2}\right]$ and $\left[\mathrm{H}_{2} \mathrm{O}_{2}\right]_{0}$ after and before the experiments as a function of time $t$. The plot demonstrates that the experiments with durations up to $6 \mathrm{~h}$ can be described by Eq. (2) in agreement with known photodegradation of $\mathrm{H}_{2} \mathrm{O}_{2}$ due to the following reaction:

$\mathrm{H}_{2} \mathrm{O}_{2}+h v \rightarrow 2 \mathrm{OH}$

We performed linear regressions separately for the high and low initial concentrations resulting in matching values for $j_{\mathrm{R} 1}$ of $0.48 \pm 0.03$ and $0.48 \pm 0.09 \mathrm{~h}^{-1}$, respectively. Here and in all further cases, the reported errors of the experimental photolysis rates are the statistical errors of the fitting procedure.

Different results were obtained in the case of the $\mathrm{HCHO}$ photolysis (Fig. 3). As reported previously [25], the decomposition of the impurity was observed with initial concentrations in the

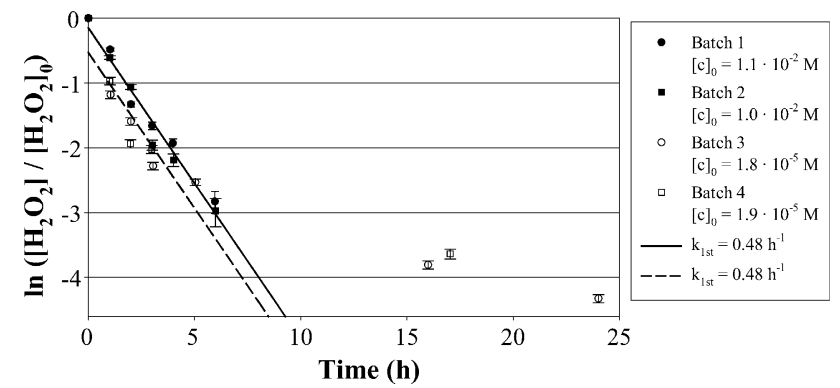

Fig. 2. Plot of the logarithm of the relative $\mathrm{H}_{2} \mathrm{O}_{2}$ concentrations before and after each photolysis experiment vs. the duration of the experiments. Different symbols represent the four different batches of artificial snow. Error bars are determined by error propagation using the analytical errors. The full line was calculated by linear regression for the high initial concentrations, the dashed line for the low initial concentrations.

$\mathrm{mM}$ range due to the following reaction:

$\mathrm{HCHO}+h v \rightarrow$ products

The experimental photolysis rate obtained from the slope of a linear regression of the data points for the high initial concentration resulted in a value of $j_{\mathrm{R} 2}=0.103 \pm 0.008 \mathrm{~h}^{-1}$. Lower initial concentrations led to puzzling results with decreasing concentrations in one of the experiments and increasing concentrations in the other two experiments. Neither experiment with low initial concentrations showed a first-order decrease as observed in the experiments with the high initial concentration.

The photolysis of $\mathrm{NO}_{3}{ }^{-}$in ice or snow leads to the formation of several products like $\mathrm{NO}_{x}, \mathrm{HONO}$, and $\mathrm{NO}_{2}^{-}$(e.g. $[10,12,18])$. Using an ion chromatography system, we were able to detect both $\mathrm{NO}_{3}{ }^{-}$and $\mathrm{NO}_{2}{ }^{-}$concentrations in the snow samples. The results are shown in Fig. 4. Initial $\mathrm{NO}_{3}{ }^{-}$concentrations were in the order of $13 \times 10^{-6} \mathrm{M}$. Even before the photolysis experiments the prepared snow always contained small amounts of $\mathrm{NO}_{2}{ }^{-}$in the order of $5-10 \times 10^{-8} \mathrm{M}$. In all experiments a first-order loss of $\mathrm{NO}_{3}{ }^{-}$was observed in the experiments lasting up to $5 \mathrm{~h}$ (Fig. 4a). A linear regression fit was performed for these data points resulting in an observed photolysis rate of $j_{\mathrm{R} 3}=0.49 \pm 0.02 \mathrm{~h}^{-1}$. Extending the duration of the photolysis further led to relatively constant $\mathrm{NO}_{3}{ }^{-}$concentrations with an average of approximately $9 \%$ of the initial $\mathrm{NO}_{3}{ }^{-}$concentrations.

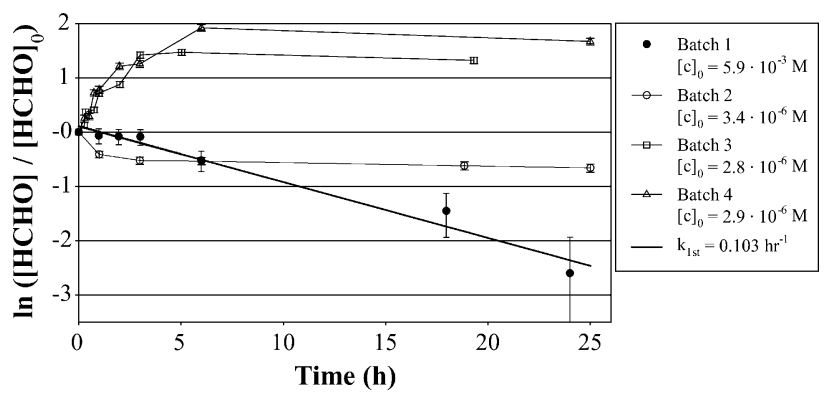

Fig. 3. Plot of the logarithm of the relative $\mathrm{HCHO}$ concentrations before and after each photolysis experiment vs. the duration of the experiments. Different symbols represent the four different batches of artificial snow. Error bars are determined by error propagation using the analytical errors. The full line was calculated by linear regression for the high initial concentrations. The lines between the open symbols are only visual guides. 


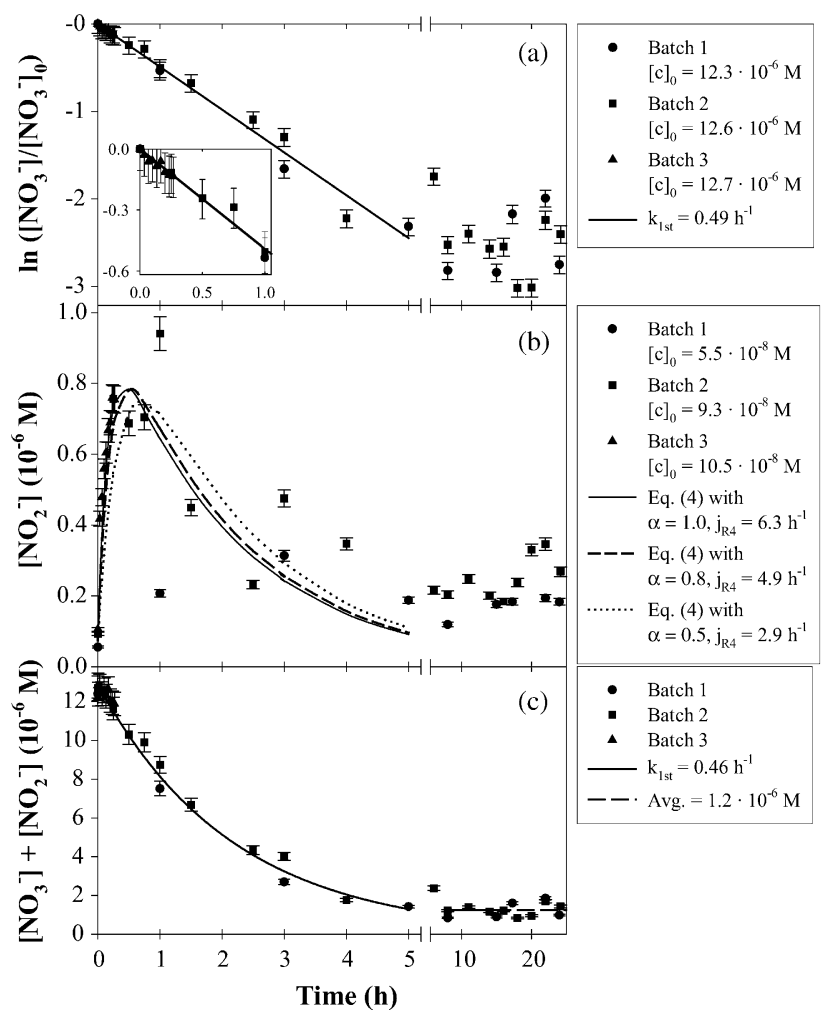

Fig. 4. (a) Plot of the logarithm of the relative $\mathrm{NO}_{3}{ }^{-}$concentrations before and after each photolysis experiment vs. the duration of the experiments. Different symbols represent the three different batches of artificial snow. Error bars are determined by error propagation using the analytical errors. The full line was calculated by linear regression for experiments with durations of up to $5 \mathrm{~h}$. The inset shows an enlargement of the results of the experiments up to $1 \mathrm{~h}$ duration. (b) Plot of the $\mathrm{NO}_{2}{ }^{-}$concentrations after each photolysis experiment vs. the duration of the experiments. Error bars are determined from the analytical errors. The lines represent calculated profiles using Eq. (5) with a range of $\mathrm{NO}_{2}{ }^{-}$yields $\alpha$ and calculated $\mathrm{NO}_{2}{ }^{-}$photolysis rates $j_{\mathrm{R} 4}$ (see text). (c) Plot of the sum of $\mathrm{NO}_{3}{ }^{-}$ and $\mathrm{NO}_{2}{ }^{-}$concentrations as a function of the duration of the experiments. Error bars are determined from the analytical errors. The full line was calculated by linear regression for the experiments with durations of up to $5 \mathrm{~h}$. The dashed line represents the average of all concentrations of the experiments beyond $8 \mathrm{~h}$ irradiation.

While $\mathrm{NO}_{3}{ }^{-}$concentrations decreased, $\mathrm{NO}_{2}{ }^{-}$concentrations showed a steep increase followed by a fast decrease leading to a maximum in the nitrite concentrations after experiments lasting between 0.5 and $1 \mathrm{~h}$. Such a concentration-time profile can be described with a simple mechanism including the simultaneous production and destruction of $\mathrm{NO}_{2}{ }^{-}$. Several laboratory studies concerning the photolysis of $\mathrm{NO}_{3}{ }^{-}$in ice $[17,18,20]$ have demonstrated that the reaction proceeds via two different channels comparable to the mechanism in the aqueous phase [30]:

$$
\begin{aligned}
& \mathrm{NO}_{3}{ }^{-}+h v\left(+\mathrm{H}^{+}\right) \rightarrow \mathrm{NO}_{2}+\mathrm{OH} \\
& \mathrm{NO}_{3}{ }^{-}+h v \rightarrow \mathrm{NO}_{2}{ }^{-}+\mathrm{O} \\
& \mathrm{NO}_{2}{ }^{-}+h v \rightarrow \text { products }
\end{aligned}
$$

Therefore, we assume that the observed overall photolysis of $\mathrm{NO}_{3}{ }^{-}$represents the sum of the two channels (R3a) and (R3b). Assuming that the reactions (R3) and (R4) are the most important driving forces for the conversion of $\mathrm{NO}_{3}{ }^{-}$to $\mathrm{NO}_{2}{ }^{-}$in our experiments, we recognize that $\mathrm{NO}_{2}{ }^{-}$is produced via reaction (R3b) and is simultaneously destroyed by the direct photolysis (R4). Taking into account the $\mathrm{NO}_{2}{ }^{-}$yield $\alpha$ for the reaction (R3), we can deduce the reaction rate law (3) for $\mathrm{NO}_{2}{ }^{-}$using the simple mechanism including reactions (R3a), (R3b), and (R4):

$$
\begin{aligned}
\frac{\mathrm{d}\left[\mathrm{NO}_{2}{ }^{-}\right]}{\mathrm{d} t} & =\alpha j_{\mathrm{R} 3}\left[\mathrm{NO}_{3}{ }^{-}\right]-j_{\mathrm{R} 4}\left[\mathrm{NO}_{2}{ }^{-}\right] \\
& =\alpha j_{\mathrm{R}_{3}}\left[\mathrm{NO}_{3}{ }^{-}\right]_{0} \exp \left(-j_{\mathrm{R} 3} t\right)-j_{\mathrm{R} 4}\left[\mathrm{NO}_{2}{ }^{-}\right]
\end{aligned}
$$

The analytical solution for Eq. (3) results in the following equation for the concentration-time profiles of $\mathrm{NO}_{2}{ }^{-}$(see Appendix A):

$$
\begin{aligned}
{\left[\mathrm{NO}_{2}{ }^{-}\right]=} & {\left[\mathrm{NO}_{2}{ }^{-}\right]_{0} \exp \left(-j_{\mathrm{R} 4} t\right)+\frac{\alpha j_{\mathrm{R} 3}\left[\mathrm{NO}_{3}{ }^{-}\right]_{0}}{j_{\mathrm{R} 4}-j_{\mathrm{R} 3}}\left[\exp \left(-j_{\mathrm{R} 3} t\right)\right.} \\
& \left.-\exp \left(-j_{\mathrm{R} 4} t\right)\right]
\end{aligned}
$$

Eq. (4) can be applied to the analysis of the measured $\mathrm{NO}_{2}{ }^{-}$ concentrations if the $\mathrm{NO}_{2}{ }^{-}$yield $\alpha$ is known. The $\mathrm{NO}_{2}{ }^{-}$yield $\alpha$ can be calculated using the quantum yields of $\mathrm{OH} \phi_{\mathrm{OH}}$ and $\mathrm{NO}_{2}{ }^{-} \phi_{\mathrm{NO}_{2}}$ - for the $\mathrm{NO}_{3}{ }^{-}$photolysis:

$\alpha=\frac{\phi_{\mathrm{NO}_{2}{ }^{-}}}{\phi_{\mathrm{OH}}+\phi_{\mathrm{NO}_{2}}{ }^{-}}$

Dubowski et al. [17,18] and Chu and Anastasio [20] investigated the $\mathrm{OH}$ and $\mathrm{NO}_{2}{ }^{-}$quantum yields of the reactions (R3a) and $(\mathrm{R} 3 \mathrm{~b})$ in ice as function of temperature and in the case of $\phi_{\mathrm{OH}}$ also as a function of wavelength. At $T=-20^{\circ} \mathrm{C}$ the obtained quantum yield $\phi_{\mathrm{OH}}$ varied between $6 \times 10^{-4}$ [17] and $2.8 \times 10^{-4}$ [20], while a quantum yield $\phi_{\mathrm{NO}_{2}}{ }^{-}$of $1.5 \times 10^{-3}$ [18] was reported. Applying these numbers we obtain values between 0.71 and 0.84 for $\alpha$.

We analyzed the $\mathrm{NO}_{2}{ }^{-}$concentrations of the batches 1-3 for experiments lasting up to $5 \mathrm{~h}$, since the temporal development of the $\mathrm{NO}_{3}{ }^{-}$concentrations in these experiments can be described by a first-order loss (Fig. 4a). The data were fitted using a Marquardt-Levenberg non-linear least squares fitting procedure in SigmaPlot (SPSS, Chicago, IL), which was performed for different $\mathrm{NO}_{2}{ }^{-}$yields $\alpha$ in the range from 1 to 0.5 accounting for the uncertainty in the reported quantum yields. The resulting concentration-time profiles are shown in Fig. $4 \mathrm{~b}$. The shape of the profiles is more or less independent of the chosen $\mathrm{NO}_{2}{ }^{-}$yield $\alpha$ in the selected range and in good agreement with the measured data. Nevertheless, the calculated $\mathrm{NO}_{2}{ }^{-}$photolysis rate $j_{\mathrm{R} 4}$ decreases by more than $50 \%$ from 6.3 to $2.9 \mathrm{~h}^{-1}$ if the $\mathrm{NO}_{2}{ }^{-}$yield $\alpha$ decreases from 1.0 to 0.5 . Fig. 5 shows the linear dependence of the calculated $\mathrm{NO}_{2}{ }^{-}$photolysis rate $j_{\mathrm{R} 4}$ as a function of the $\mathrm{NO}_{2}{ }^{-}$yield $\alpha$. Taking also into account the high variability of the measured $\mathrm{NO}_{2}{ }^{-}$concentrations for the different snow batches (Fig. 4b), the $\mathrm{NO}_{2}{ }^{-}$photolysis rate remains rather uncertain. Moreover, the additional reaction of $\mathrm{NO}_{2}{ }^{-}$with the $\mathrm{OH}$ radical produced in reaction (R3b) could also contribute to the destruction of $\mathrm{NO}_{2}{ }^{-}$. The effect of such reaction increases with a decreasing $\mathrm{NO}_{2}{ }^{-}$yield $\alpha$. Nevertheless, the experimental 


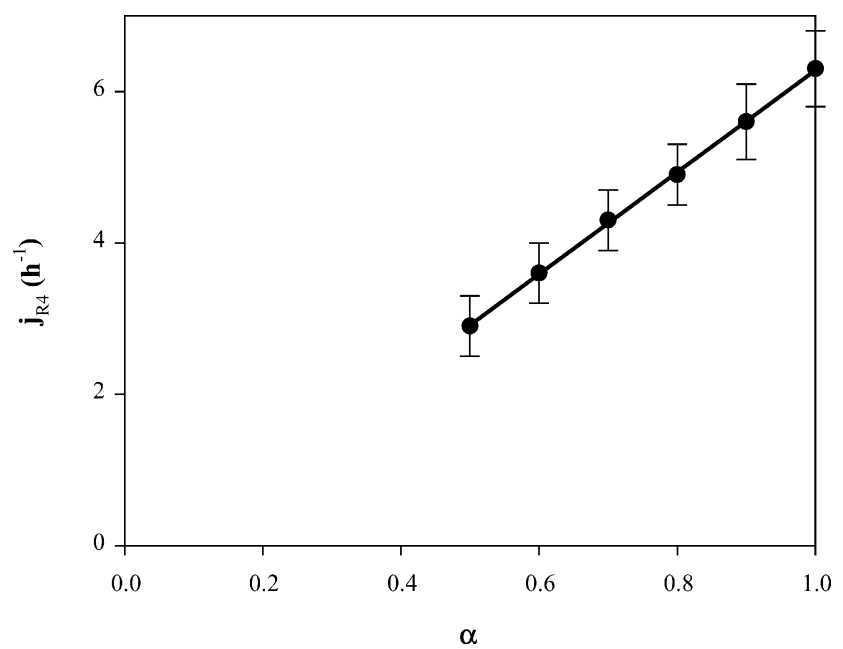

Fig. 5. Calculated experimental rates $j_{\mathrm{R} 4}$ for the photolysis of $\mathrm{NO}_{2}{ }^{-}$as a function of the $\mathrm{NO}_{2}{ }^{-}$yield $\alpha$ of the $\mathrm{NO}_{3}{ }^{-}$photolysis. The photolysis rates were obtained by non-linear least squares fitting procedures using Eq. (4) with varying $\mathrm{NO}_{2}{ }^{-}$ yields (see text). The error bars represent calculated statistical errors. The line shows the result of a linear regression using all data points $\left(R^{2}=0.9995\right)$.

photolysis rate of $\mathrm{NO}_{2}{ }^{-}$is certainly higher than the photolysis rate of $\mathrm{NO}_{3}{ }^{-}$.

We also analyzed the concentrations of total nitrogen in the snow as the sum of the concentrations of $\mathrm{NO}_{3}{ }^{-}$and $\mathrm{NO}_{2}{ }^{-}$. Since $\mathrm{NO}_{3}{ }^{-}$dominates the total nitrogen budget, we also obtained an exponential decay with increasing durations of the experiments (Fig. 4c). The first-order loss rate of $j=0.46 \pm 0.01 \mathrm{~h}^{-1}$ is calculated by linear regression for the experiments with durations up to $5 \mathrm{~h}$ and is somewhat smaller than the overall photolysis rate of $\mathrm{NO}_{3}{ }^{-}$. Total nitrogen in the snow remained relatively constant beyond $8 \mathrm{~h}$ irradiation. The average of the remaining nitrogen amounts to $(1.2 \pm 0.2) \times 10^{-6} \mathrm{M}$, which constitutes approximately $10 \%$ of the initial nitrogen concentrations.

\section{Discussion}

Our results permit the comparison of the photolysis reactions of different trace compounds in snow, since the experiments were performed under similar conditions allowing the evaluation of relative photolysis rates of the different compounds. The smallest photolysis rate of $0.103 \pm 0.008 \mathrm{~h}^{-1}$ was observed in the case of $\mathrm{HCHO}$, while the $\mathrm{H}_{2} \mathrm{O}_{2}$ and $\mathrm{NO}_{3}{ }^{-}$photolysis rates of $0.48 \pm 0.09$ and $0.49 \pm 0.02 \mathrm{~h}^{-1}$ are comparable. Moreover, a decomposition of $\mathrm{HCHO}$ was only observable with high initial concentrations. Similar results for $\mathrm{HCHO}$ and $\mathrm{H}_{2} \mathrm{O}_{2}$ with initial concentrations in the $\mathrm{mM}$ range were reported previously [25]. This order of the photolysis rates agrees well with the absorption spectra of the three compounds in the aqueous phase as shown in Fig. 1. While $\mathrm{H}_{2} \mathrm{O}_{2}$ and $\mathrm{NO}_{3}{ }^{-}$show significant absorption bands overlapping with the emission spectrum of the lamp, the $\mathrm{HCHO}$ absorption is significantly lower.

The disagreeing results obtained in the experiments with low initial $\mathrm{HCHO}$ concentrations are possibly due to the fact that a simultaneous photochemical production of $\mathrm{HCHO}$ in snow occurs. Similar results were reported by Grannas et al. [5], who found increasing $\mathrm{HCHO}$ concentrations in snow samples from the Arctic and the Antarctic after irradiating with UV radiation. They concluded that the HCHO production is caused by the presence of organic material in the snow, which undergoes oxidation either through photolysis or the attack by $\mathrm{OH}$ radicals. Similar processes are possible in our experiments, too. Although using Milli-Q water, the prepared solutions and therefore the snow samples will not be absolutely carbon-free. The maximum $\mathrm{HCHO}$ increase observed in the experiments with the batches 3 and 4 corresponds to $10 \times 10^{-6}$ or $17 \times 10^{-6} \mathrm{M}$ (Fig. 3). However, such large contaminations of the Milli-Q water with organic matter seem very unlikely. We rather suspect that the snow became contaminated during the production process of the artificial snow. This could also explain the disagreeing results including the observation of an $\mathrm{HCHO}$ decrease in the case of batch 2 showing that possibly no contamination occurred in this case (Fig. 3). Interestingly, such contaminations seem to have a negligible effect on the $\mathrm{H}_{2} \mathrm{O}_{2}$ decomposition. In the atmospheric gas and aqueous phase $\mathrm{H}_{2} \mathrm{O}_{2}$ is formed by the recombination of two $\mathrm{HO}_{2}$ radicals [31]. Although $\mathrm{HO}_{2}$ is also produced during the oxidation of organic compounds, the formation rate of $\mathrm{H}_{2} \mathrm{O}_{2}$ in snow seems to be much smaller compared to $\mathrm{HCHO}$. This is in agreement with previous field studies as summarized by Dominé and Shepson [2], who concluded that photochemical reactions in surface snow can lead to the production of carbonyl compounds. In contrast, the photochemical production of $\mathrm{H}_{2} \mathrm{O}_{2}$ in surface snow has not been observed yet (e.g. [32]). Moreover, from laboratory experiments Anastasio and Jordan [33] deduced $\mathrm{H}_{2} \mathrm{O}_{2}$ formation rates in the snowpack of Alert, Canada, caused by the deposition and photolysis of particulate chromophores. Compared to the bulk $\mathrm{H}_{2} \mathrm{O}_{2}$ concentration in the snow, they found that the photoformation is probably only a minor source.

Under the applied experimental conditions, the $\mathrm{H}_{2} \mathrm{O}_{2}$ and $\mathrm{NO}_{3}{ }^{-}$photolysis reactions occur equally fast in the snow. This result would have important implications for the photochemistry occurring in natural snow covers, because the photolysis of $\mathrm{NO}_{3}{ }^{-}$in ice and snow has recently attracted a lot of interest. Field [8-14] and laboratory experiments [16-19] have demonstrated that the $\mathrm{NO}_{3}{ }^{-}$photolysis in surface snow is responsible for the formation of reactive nitrogen oxides like $\mathrm{NO}, \mathrm{NO}_{2}$, and HONO in the surface snow, which are subsequently emitted to the atmosphere $[12,14,34-36]$ influencing the chemistry of the boundary layer above the snow cover. Moreover, the $\mathrm{NO}_{3}{ }^{-}$photolysis is widely regarded as a source of $\mathrm{OH}$ radicals in surface snow, which initiates several oxidation reactions. Unfortunately, our experimental conditions are not directly comparable to conditions in the natural surface snow regarding the irradiation intensity and spectrum and the generation of the snow. For example, Jacobi et al. [25] reported that in the range from 300 to $370 \mathrm{~nm}$ the integral irradiation intensity of the lamp is more than 40 times higher than the maximum solar irradiance measured at a coastal station in Antarctica. Moreover, the lamp emits irradiation in the UV range down to $230 \mathrm{~nm}$, which is only partly absorbed by the water filter, while the actinic flux reaching the Earth's surface becomes negligible below wavelengths of $290 \mathrm{~nm}$ (Fig. 1). Therefore, the relative rate of the 
$\mathrm{H}_{2} \mathrm{O}_{2}$ photolysis to the $\mathrm{NO}_{3}{ }^{-}$photolysis is probably higher in our experiments compared to natural conditions because the absorption coefficients of $\mathrm{H}_{2} \mathrm{O}_{2}$ in the aqueous phase in the range of 230-280 $\mathrm{nm}$ are higher than the comparable absorption coefficients of $\mathrm{NO}_{3}^{-}$(Fig. 1). Nevertheless, the experiments demonstrate that the photochemistry in natural snow covers is not only driven by the $\mathrm{NO}_{3}{ }^{-}$photolysis, but also by the photolysis of other light-absorbing species. Since $\mathrm{H}_{2} \mathrm{O}_{2}$ is omni-present in natural snow samples (e.g. [3]), its photolysis needs to be taken into account if an accurate description of the photochemistry is required. Chu and Anastasio [21] even concluded that in all investigated polar environments the $\mathrm{OH}$ production in the surface snow could be dominated by the $\mathrm{H}_{2} \mathrm{O}_{2}$ photolysis. The produced $\mathrm{OH}$ radicals can have a further impact on the conversion of higher organic compounds like chlorophenols in the snow as discussed by Klánová et al. [37].

Only in the case of the $\mathrm{NO}_{3}{ }^{-}$photolysis a direct observation of the formation of one of the products was possible. Our measurements show that the generated $\mathrm{NO}_{2}{ }^{-}$is itself photo labile and undergoes a photochemical reaction, which is faster than the $\mathrm{NO}_{3}{ }^{-}$photolysis as expected from a comparison of the absorption spectra of both compounds (Fig. 1). According to processes in the aqueous phase [30], the most likely products of the $\mathrm{NO}_{2}{ }^{-}$ photolysis are $\mathrm{NO}$ and $\mathrm{O}^{-} . \mathrm{O}^{-}$is quickly protonated forming the $\mathrm{OH}$ radical. Therefore, each photolyzed $\mathrm{NO}_{3}{ }^{-}$molecule results in the formation of one $\mathrm{OH}$ molecule either directly in reaction (R3a) or via the $\mathrm{NO}_{2}{ }^{-}$photolysis. Further, $\mathrm{N}$-containing products are the nitrogen oxides $\mathrm{NO}$ and $\mathrm{NO}_{2}$. These are highly volatile and thus are probably released to the gas phase. The $\mathrm{NO}_{x}$ production and release to the gas phase as a result of the radiation of $\mathrm{NO}_{3}{ }^{-}$dissolved in ice or snow has been observed in several laboratory studies $[16,17,19]$. Therefore, we conclude that the missing fraction of the initial total nitrogen in the snow in our experiments constitutes the released $\mathrm{NO}_{x}$. Since our experiments are performed in closed cells, the generated nitrogen oxides cannot escape. The volume of the gas phase in the experimental cells amounts to about $24 \mathrm{~cm}^{3}$. The missing fraction of total nitrogen in the experiments lasting longer than $8 \mathrm{~h}$ is about $11 \times 10^{-6} \mathrm{M}$ (Fig. 4c). With a mass of snow of approximately $8 \mathrm{~g}$, the released amount of nitrogen would result in the formation of more than 70 ppmV $\mathrm{NO}_{x}$ in the gas phase of the cells. Under these conditions side reactions are likely leading to the reformation of $\mathrm{NO}_{3}{ }^{-}$in the snow. Therefore, we assume that the constant total nitrogen in the snow in the experiments lasting longer than $8 \mathrm{~h}$ is due to the recycling of $\mathrm{NO}_{3}{ }^{-}$from $\mathrm{NO}_{x}$ previously released to the gas phase of the cells.

Like in the gas and aqueous phase, the photolysis of $\mathrm{H}_{2} \mathrm{O}_{2}$ in ice samples leads to the formation of $\mathrm{OH}$ radicals, which was demonstrated by using a radical scavenger like benzoic acid [21]. Thus, we assume that $\mathrm{OH}$ radicals are also produced upon the photolysis of $\mathrm{H}_{2} \mathrm{O}_{2}$ in the artificial snow like in our experiments. In the case of $\mathrm{HCHO}$ the products are not well known. In the aqueous phase more than $99 \%$ of the $\mathrm{HCHO}$ is hydrated forming the gem-diol $\left(\mathrm{CH}_{2}(\mathrm{OH})_{2}\right)$, which is much more soluble in water [38]. However, the absorption of radiation in the UV and visible range by the gem-diol form is negligible (Fig. 1). Moreover, Couch et al. [39] concluded from snow chamber experiments that the $\mathrm{HCHO}$ present in the surface layer of natural snow grains is most likely not hydrated. We are currently not able to distinguish if the hydrated or non-hydrated form of $\mathrm{HCHO}$ is present in the artificial snow. Nevertheless, the HCHO decay observed with the high initial concentration point to the fact that under these conditions a significant $\mathrm{HCHO}$ fraction must be present in the non-hydrated from. Due to the properties of the carbonyl group only the non-hydrated $\mathrm{HCHO}$ can absorb the applied radiation as demonstrated by the absorption spectrum of $\mathrm{HCHO}$ in the gas phase (Fig. 1). If $\mathrm{HCHO}$ is the photochemically active form in our experiments, we must consider that two different reaction channels are possible like in the gas phase [1]:

$$
\begin{aligned}
& \mathrm{HCHO}+h v \rightarrow \mathrm{H}+\mathrm{CHO} \\
& \mathrm{HCHO}+h v \rightarrow \mathrm{H}_{2}+\mathrm{CO}
\end{aligned}
$$

In the gas phase the products formed in reaction channel (R2a) quickly undergo subsequent reactions with $\mathrm{O}_{2}$ generating compounds like $\mathrm{HO}_{2}$ and $\mathrm{CO}$ [1]. However, further studies concerning the possible stable products like $\mathrm{CO}$ will be needed to elucidate the reaction mechanism of the $\mathrm{HCHO}$ photolysis in snow. Due to the volatility of CO it is also likely that it is released to the gas phase, where it would be possible to quantify the $\mathrm{CO}$ production with a high time resolution.

Large fractions of all three investigated compounds are removed from the snow during the long-term experiments. For example, less than $2 \%$ of the initial $\mathrm{H}_{2} \mathrm{O}_{2}$ was found in the snow after an irradiation period of $24 \mathrm{~h}$ (Fig. 2). Remaining fractions of $\mathrm{HCHO}$ and total nitrogen in the snow amounted to values around $10 \%$ (Figs. 3 and 4c). As discussed above, the most likely fate of the reaction products in the case of the $\mathrm{NO}_{3}{ }^{-}$photolysis is the release to the gas phase. However, even for the longest experiments the diffusion of $\mathrm{NO}_{3}{ }^{-}$in the solid ice is negligible. A diffusion coefficient of $6.6 \times 10^{-11} \mathrm{~cm}^{2} \mathrm{~s}^{-1}$ was reported for $\mathrm{HNO}_{3}$ in ice at $-20^{\circ} \mathrm{C}$ [40]. Using $\left\langle x^{2}\right\rangle=2 \mathrm{Dt}$ and $t \leq 25 \mathrm{~h}=90,000 \mathrm{~s}$, the maximum traveled distance $x$ of $\mathrm{HNO}_{3}$ amounts to $34 \mu \mathrm{m}$, which is small compared to the maximum radius of the snow crystals of $250 \mu \mathrm{m}$. This indicates that before the start of the experiments a large fraction of the $\mathrm{NO}_{3}{ }^{-}$must be present close to the surface enabling a quick transfer of the products from the snow to the gas phase. This is somewhat surprising since due to the applied snow production method involving the shock-freezing of the solution in liquid nitrogen a rather uniform distribution of the $\mathrm{NO}_{3}{ }^{-}$throughout the snow grains would be plausible. The diffusion of $\mathrm{NO}_{3}{ }^{-}$to the surface of the snow grains during the storage time of the artificial snow is also not feasible because with the above mentioned diffusion coefficient a period of more than 50 days would be necessary to move a distance of $250 \mu \mathrm{m}$ within the solid ice. In contrast, the maximum storage time of the samples was less than 3 weeks. Regarding the $\mathrm{NO}_{3}{ }^{-}$distribution in the snow grains, the artificial snow seems to resemble natural snow quite closely. For example, Jacobi et al. [41] concluded from measurements of $\mathrm{HNO}_{3}$ in the interstitial air of the surface snow and nitrate measurements in the snow in Greenland, that $80-100 \%$ of the nitrate is present in the surface layer of the snow grains. Since we did not follow the product formation during the experiments with $\mathrm{H}_{2} \mathrm{O}_{2}$ and $\mathrm{HCHO}$, we are 
not able to determine the distribution of these trace compounds within the snow grains.

\section{Conclusions}

Our results show that the photochemistry occurring in the sunlit snow is very diverse. Besides the photolysis of $\mathrm{NO}_{3}{ }^{-}$, the photolysis of $\mathrm{H}_{2} \mathrm{O}_{2}$ seems to be fast enough to contribute to the formation of $\mathrm{OH}$ radicals in the snow. Like in the tropospheric gas and aqueous phase the $\mathrm{OH}$ radical is probably the most important driving force for the oxidation of organic compounds in sunlit snow. The oxidation likely leads to the formation of volatile compounds such as aldehydes, ketones, and carboxylic acids. Most of these compounds have been detected in surface snow even in the remote polar areas [15,42,43]. Moreover, the emissions of several volatile compounds from the sunlit snow have been observed in the Arctic [44-46] influencing the chemistry in the boundary layer in snow-covered areas [2]. $\mathrm{OH}$ radicals can also contribute to the formation and release of molecular chlorine $\left(\mathrm{Cl}_{2}\right)$ and bromine $\left(\mathrm{Br}_{2}\right)$ if the snow contains chloride and bromide [2]. $\mathrm{Cl}_{2}$ and $\mathrm{Br}_{2}$ are easily photolyzed by radiation in the visible range forming halogen atoms [1], which can contribute to the removal of ozone, the oxidation of organic compounds, and the formation and deposition of reactive gaseous mercury [47]. Therefore, photochemical reactions in the snow have the potential to alter the surface snow composition as well as the composition of the boundary layer above snow-covered areas.

One of the major effects of a changing snow composition is the interpretation of concentration profiles in firn and ice cores. The interpretation of $\mathrm{NO}_{3}{ }^{-}$profiles is currently hampered by the fact that a transfer function relating snow and atmospheric concentrations has not been established. A fast drop in $\mathrm{NO}_{3}{ }^{-}$ concentrations in the surface snow with depth has been recorded at several polar locations [48]. However, the drop is probably caused by a site-specific combination of the photolysis and the re-evaporation of deposited $\mathrm{NO}_{3}{ }^{-}$. Unfortunately, the different contributions have not been quantified yet, although several investigations have indicated that the photolysis is a minor, albeit not negligible factor (e.g. [48,49]). Since the $\mathrm{H}_{2} \mathrm{O}_{2}$ photolysis in snow occurs at a comparable rate, we suggest that at least for low accumulation sites, where the surface snow is exposed to the solar radiation for long periods, the photodecomposition of $\mathrm{H}_{2} \mathrm{O}_{2}$ needs to be taken into account.

In the case of $\mathrm{NO}_{3}{ }^{-}$, we concluded that a large fraction of the trace compound was located close to the surface of the snow grains. This indicates that although the artificial snow production process is vastly different from the process of ice crystal formation in the atmosphere, the distribution of this specific compound is comparable in natural and artificial snow grains. Nevertheless, further laboratory experiments are needed including the simultaneous investigation of the decomposition of the initial trace compound and the formation of stable products either in the snow or in the adjacent gas phase. With such experiments more information about the reaction mechanism, the product distribution, and the distribution of the trace compounds within the snow grains can be obtained.

\section{Acknowledgements}

Financial support by the Deutsche Forschungsgemeinschaft (DFG), grant JA 932/5-1, is gratefully acknowledged. We thank the two anonymous reviewers for valuable comments.

\section{Appendix A}

The reaction rate law for $\mathrm{NO}_{2}{ }^{-}$(Eq. (A1)) can be transformed into a differential equation (Eq. (A2)) with a general analytical solution (Eq. (A3)) with the differentiation constant diff const $_{\text {and }}$ the further constants $c_{1}-c_{3}$.

$$
\begin{aligned}
& \frac{d\left[\mathrm{NO}_{2}{ }^{-}\right]}{\mathrm{d} t}=\alpha j_{\mathrm{R} 3}\left[\mathrm{NO}_{3}{ }^{-}\right]_{0} \exp \left(-j_{\mathrm{R} 3} t\right)-j_{\mathrm{R} 4}\left[\mathrm{NO}_{2}{ }^{-}\right] \\
& y^{\prime}+c_{1} y=c_{2} \exp \left(-c_{3} t\right) \\
& y=\operatorname{diff}_{\text {const }} \exp \left(-c_{1} t\right)+\frac{c_{2}}{c_{1}-c_{3}} \exp \left(-c_{3} t\right)
\end{aligned}
$$

The transformed rate law corresponds to the equation (Eq. (A4)):

$$
\frac{d\left[\mathrm{NO}_{2}{ }^{-}\right]}{\mathrm{d} t}+j_{\mathrm{R} 4}\left[\mathrm{NO}_{2}{ }^{-}\right]=\alpha j_{\mathrm{R} 3}\left[\mathrm{NO}_{3}{ }^{-}\right]_{0} \exp \left(-j_{\mathrm{R} 3} t\right)
$$

with the constants $c_{1}=j_{\mathrm{R} 4}, c_{2}=\alpha j_{\mathrm{R} 3}\left[\mathrm{NO}_{3}{ }^{-}\right]_{0}$, and $c_{3}=j_{\mathrm{R} 3}$. Introducing these constants into (Eq. (A3)) yields the following solution for the reaction rate law:

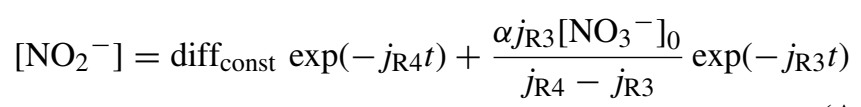

The $\mathrm{NO}_{2}{ }^{-}$concentration at $t=0$ is set to the initial $\mathrm{NO}_{2}{ }^{-}$ concentration $\left[\mathrm{NO}_{2}{ }^{-}\right]_{0}$ and can be used to calculate the differentiation constant diff const $_{\text {: }}$

$\operatorname{diff}_{\text {const }}=\left[\mathrm{NO}_{2}{ }^{-}\right]_{0}-\frac{\alpha j_{\mathrm{R} 3}\left[\mathrm{NO}_{3}{ }^{-}\right]_{0}}{j_{\mathrm{R} 4}-j_{\mathrm{R} 3}}$

Applying this constant, we derive the final expression for the reaction rate law of $\mathrm{NO}_{2}^{-}$:

$$
\begin{aligned}
{\left[\mathrm{NO}_{2}{ }^{-}\right]=} & {\left[\mathrm{NO}_{2}{ }^{-}\right]_{0} \exp \left(-j_{\mathrm{R} 4} t\right)+\frac{\alpha j_{\mathrm{R} 3}\left[\mathrm{NO}_{3}{ }^{-}\right]_{0}}{j_{\mathrm{R} 4}-j_{\mathrm{R} 3}}\left[\exp \left(-j_{\mathrm{R} 3} t\right)\right.} \\
& \left.-\exp \left(-j_{\mathrm{R} 4} t\right)\right]
\end{aligned}
$$

\section{References}

[1] B.J. Finlayson-Pitts, J.N. Pitts, Chemistry of the Upper and Lower Atmosphere: Theory, Experiments, and Applications, Academic Press, San Diego, 2000.

[2] F. Dominé, P.B. Shepson, Air-snow interactions and atmospheric chemistry, Science 279 (2002) 1506-1510.

[3] M. Legrand, P. Mayewski, Glaciochemistry of polar ice cores: a review, Rev. Geophys. 35 (1997) 219-243.

[4] C. Anastasio, A.L. Jordan, Photoformation of hydroxyl radical and hydrogen peroxide in aerosol particles from Alert, Nunavut: implications for aerosol and snowpack chemistry in the Arctic, Atmos. Environ. 38 (2004) 1153-1166. 
[5] A.M. Grannas, P.B. Shepson, T.R. Filley, Photochemistry and nature of organic matter in Arctic and Antarctic snow, Global Biogeochem. Cycles 18 (GB1006) (2004), doi:10.1029/2003GB002133.

[6] M.D. King, W.R. Simpson, The extinction of UV radiation in Arctic snow at Alert, Canada $\left(82^{\circ} \mathrm{N}\right)$, J. Geophys. Res. 106 (2001) 12499-12507.

[7] M. Peterson, D. Barber, S. Green, Monte Carlo modeling and measurements of actinic flux levels in Summit, Greenland snowpack, Atmos. Environ. 36 (2002) 2545-2551.

[8] R.E. Honrath, M.C. Peterson, S. Guo, J.E. Dibb, P.B. Shepson, B. Campbell, Evidence of $\mathrm{NO}_{x}$ production within or upon ice particles in the Greenland snowpack, Geophys. Res. Lett. 26 (1999) 695-698.

[9] R.E. Honrath, M.C. Peterson, M.P. Dziobak, J.E. Dibb, M.A. Arsenault, S.A. Green, Release of $\mathrm{NO}_{x}$ from sunlight-irradiated midlatitude snow, Geophys. Res. Lett. 27 (2000) 2237-2240.

[10] A.E. Jones, R. Weller, E.W. Wolff, H.-W. Jacobi, Speciation and rate of photochemical $\mathrm{NO}$ and $\mathrm{NO}_{2}$ production in Antarctic snow, Geophys. Res. Lett. 27 (2000) 345-348.

[11] B. Ridley, J. Walega, D. Montzka, F. Grahek, E. Atlas, F. Flocke, V. Stroud, J. Deary, A. Gallant, H. Boudries, J. Bottenheim, K. Anlauf, D. Worthy, A.L. Sumner, B. Splawn, P. Shepson, Is the Arctic surface layer a source and sink of $\mathrm{NO}_{x}$ in winter/spring? J. Atmos. Chem. 36 (2000) $1-22$.

[12] X. Zhou, H.J. Beine, R.E. Honrath, J.D. Fuentes, W. Simpson, P.B. Shepson, J.W. Bottenheim, Snowpack photochemical production of HONO: a major source of $\mathrm{OH}$ in the arctic boundary layer in springtime, Geophys. Res. Lett. 28 (2001) 4087-4090.

[13] D. Davis, J.B. Nowak, G. Chen, M. Buhr, R. Arimoto, A. Hogan, F. Eisele, L. Mauldin, D. Tanner, R. Shetter, B. Lefer, P. McMurry, Unexpected high levels of NO observed at South Pole, Geophys. Res. Lett. 28 (2001) 3625-3628.

[14] R.E. Honrath, Y. Lu, M.C. Peterson, J.E. Dibb, M.A. Arsenault, N.J. Cullen, K. Steffen, Vertical fluxes of $\mathrm{NO}_{x}, \mathrm{HONO}$, and $\mathrm{HNO}_{3}$ above the snowpack at Summit, Greenland, Atmos. Environ. 36 (2002) 2629-2640.

[15] A.L. Sumner, P.B. Shepson, Snowpack production of formaldehyde and its effect on the Arctic troposphere, Nature 398 (1999) 230-233.

[16] R.E. Honrath, S. Guo, M.C. Peterson, M.P. Dziobak, J.E. Dibb, M.A. Arsenault, Photochemical production of gas phase $\mathrm{NO}_{x}$ from ice crystal $\mathrm{NO}_{3}{ }^{-}$, J. Geophys. Res. 105 (2000) 24183-24190.

[17] Y. Dubowski, A.J. Colussi, M.R. Hoffmann, Nitrogen dioxide release in the $302 \mathrm{~nm}$ band photolysis of spray-frozen aqueous nitrate solutions. Atmospheric implications, J. Phys. Chem. A 105 (2001) 4928-4932.

[18] Y. Dubowski, A.J. Colussi, C. Boxe, M.R. Hoffmann, Monotonic increase of nitrite yields in the photolysis of nitrate in ice and water between 238 and 294 K, J. Phys. Chem. A 106 (2002) 6967-6971.

[19] E.S.N. Cotter, A.E. Jones, E.W. Wolff, S.J.-B. Baugitte, What controls photochemical $\mathrm{NO}$ and $\mathrm{NO}_{2}$ production from Antarctic snow? Laboratory investigation assessing the wavelength and temperature dependence, J. Geophys. Res. 108 (D4) (2003) 4147, doi:10.1029/2002JD002602.

[20] L. Chu, C. Anastasio, Quantum yields of hydroxyl radical and nitrogen dioxide from the photolysis of nitrate on ice, J. Phys. Chem. A 107 (2003) 9594-9602.

[21] L. Chu, C. Anastasio, Formation of hydroxyl radical from the photolysis of frozen hydrogen peroxide, J. Phys. Chem. A 109 (28) (2005) 6264-6271.

[22] D. Haan, Y. Zuo, V. Gros, C.A.M. Brenninkmeijer, Photochemical production of carbon monoxide in snow, J. Atmos. Chem. 40 (2001) 217-230.

[23] P. Klán, I. Holoubek, Ice (photo)chemistry. Ice as a medium for long-term (photo)chemical transformations-environmental implications, Chemosphere 46 (2002) 1201-1210.

[24] P. Klán, J. Klánová, I. Holoubek, P. Čupr, Photochemical activity of organic compounds in ice induced by sunlight irradiation: the Svalbard project, Geophys. Res. Lett. 30 (6) (2003) 1313, doi:10.1029/2002GL016385.

[25] H.-W. Jacobi, B. Kwakye-Awuah, O. Schrems, Photochemical decomposition of hydrogen peroxide $\left(\mathrm{H}_{2} \mathrm{O}_{2}\right)$ and formaldehyde $(\mathrm{HCHO})$ in artificial snow, Ann. Glaciol. 39 (2004) 29-33.
[26] T. Staffelbach, A. Neftel, B. Stauffer, D. Jacob, A record of atmospheric methane sink from formaldehyde in polar ice cores, Nature 349 (1991) 603-605.

[27] K. Riedel, R. Weller, O. Schrems, Variability of formaldehyde in the Antarctic troposphere, Phys. Chem. Chem. Phys. 1 (1999) 5523-5527.

[28] K. Riedel, R. Weller, O. Schrems, G. König-Langlo, Variability of tropospheric hydroperoxides at a coastal surface site in Antarctica, Atmos. Environ. 34 (2000) 5225-5234.

[29] F. Göktas, H. Fischer, H. Oerter, R. Weller, S. Sommer, H. Miller, A glacio-chemical characterization of the new EPICA deep-drilling site on Amundsenisen, Dronning Maud Land, Antarctica, Ann. Glaciol. 35 (2002) 347-354.

[30] J. Mack, J.R. Bolton, Photochemistry of nitrite and nitrate in aqueous solution: a review, J. Photochem. Photobiol. A 128 (1999) 1-13.

[31] A.V. Jackson, C.N. Hewitt, Atmosphere hydrogen peroxide and organic hydroperoxides: a review, Crit. Rev. Environ. Sci. Technol. 29 (1999) $175-228$.

[32] H.-W. Jacobi, M.M. Frey, M.A. Hutterli, R.C. Bales, O. Schrems, N.J. Cullen, K. Steffen, C. Koehler, Measurements of hydrogen peroxide and formaldehyde exchange between the atmosphere and surface snow at Summit, Greenland, Atmos. Environ. 36 (2002) 2619-2628.

[33] C. Anastasio, A.L. Jordan, Photoformation of hydroxyl radical and hydrogen peroxide in aerosol particles from Alert, Nunavut: implications for aerosol and snowpack chemistry in the Arctic, Atmos. Environ. 38 (2004) 1153-1166.

[34] A.E. Jones, R. Weller, P.S. Anderson, H.-W. Jacobi, E.W. Wolff, O. Schrems, H. Miller, Measurements of $\mathrm{NO}_{x}$ emissions from the Antarctic snowpack, Geophys. Res. Lett. 28 (2001) 1499-1502.

[35] J.E. Dibb, M. Arsenault, M.C. Peterson, R.E. Honrath, Fast nitrogen oxide photochemistry in Summit, Greenland snow, Atmos. Environ. 36 (2002) 2501-2511.

[36] H.J. Beine, R.E. Honrath, F. Dominé, W.R. Simpson, J.D. Fuentes, $\mathrm{NO}_{x}$ during background and ozone depletion periods at Alert: fluxes above the snow surface, J. Geophys. Res. 107 (D21) (2002) 4584, doi:10.1029/2002JD002082.

[37] J. Klánová, P. Klán, D. Heger, I. Holoubek, Compariosn of the effects of UV, $\mathrm{H}_{2} \mathrm{O}_{2} / \mathrm{UV}$ and $\gamma$-irradiation processes on frozen and liquid water solutions of monochlorphenols, Photochem. Photobiol. Sci. 2 (2003) 1023-1031.

[38] R.P. Bell, The reversible hydration of carbonyl compounds, Adv. Phys. Org. Chem 4 (1966) 1-29.

[39] T.L. Couch, A.L. Sumner, T.M. Dassau, P.B. Shepson, R.E. Honrath, An investigation of the interaction of carbonyl compounds with the snowpack, Geophys. Res. Lett. 27 (2000) 2241-2244.

[40] E. Thibert, F. Dominé, Thermodynamics and kinetics of the solid solution of $\mathrm{HNO}_{3}$ in ice, J. Phys. Chem. B 102 (1998) 4432-4439.

[41] H.-W. Jacobi, R.C. Bales, R.E. Honrath, M.C. Peterson, J.E. Dibb, A.L. Swanson, M.R. Albert, Reactive trace gases measured in the interstitial air of surface snow at Summit, Greenland, Atmos. Environ. 38 (12) (2004) 1687-1697.

[42] J.E. Dibb, M. Arsenault, Should not snowpacks be a source of monocarboxylic acids? Atmos. Environ. 36 (2002) 2513-2522.

[43] S. Houdier, S. Perrier, F. Dominé, A. Cabanes, L. Legagneux, A.M. Grannas, C. Guimbaud, P.B. Shepson, H. Boudries, J.W. Bottenheim, Acetaldehyde and acetone in the Arctic snowpack during the ALERT2000 campaign. Snowpack composition, incorporation processes and atmospheric impact, Atmos. Environ. 36 (2002) 2609-2618.

[44] H. Boudries, J.W. Bottenheim, C. Guimbaud, A.M. Grannas, P.B. Shepson, S. Houdier, S. Perrier, F. Dominé, Distribution and trends of oxygenated hydrocarbons in the high arctic derived from measurements in the atmospheric boundary layer and interstitial snow air during the ALERT2000 field campaign, Atmos. Environ. 36 (2002) 25732583.

[45] A.M. Grannas, P.B. Shepson, C. Guimbaud, A.L. Sumner, M. Albert, W. Simpson, F. Domine, H. Boudries, J. Bottenheim, H.J. Beine, R. Honrath, X. Zhou, A study of photochemical and physical processes affecting carbonyl compounds in the Arctic atmospheric boundary layer, Atmos. Environ. 36 (2002) 2733-2742. 
[46] C. Guimbaud, A.M. Grannas, P.B. Shepson, J.D. Fuentes, H. Boudries, J.W. Bottenheim, F. Dominé, S. Houdier, S. Perrier, T.B. Bisenthal, B.G. Splawn, Snowpack processing of acetaldehyde and acetone in the arctic atmospheric boundary layer, Atmos. Environ. 36 (2002) 2743-2752.

[47] W.H. Schroeder, K.G. Anlauf, L.A. Barrie, J.Y. Lu, A. Steffen, D.R. Schneeberger, T. Berg, Arctic springtime depletion of mercury, Nature 394 (1998) 331-332.

[48] R. Röthlisberger, M.A. Hutterli, E.W. Wolff, R. Mulvaney, H. Fischer, M. Bigler, K. Goto-Azuma, M.E. Hansson, U. Ruth, M.-L. SiggaardAndersen, J.P. Steffensen, Nitrate in Greenland and Antarctic ice cores: a detailed description of post-depositional processes, Ann. Glaciol. 35 (2002) 209-216.
[49] T. Blunier, G.L. Floch, H.-W. Jacobi, E. Quansah, Isotopic view on nitrate loss in Antarctic surface snow, Geophys. Res. Lett. 32 (2005) L13501, doi:10.1029/2005GL023011.

[50] S. Wuttke, Radiation conditions in an Antarctic environment, accessible at http://www.muk.uni-hannover.de/institut/bibliothek/pdf-diss/ Dissertation_Wuttke.pdf, Ph.D. Thesis, University Hannover, Germany, 2005.

[51] S.J. Strickler, M. Kasha, Solvent effects on the electronic absorption spectrum of nitrite ion, J. Am. Chem. Soc. 85 (1963) 2899-2901.

[52] R. Meller, G.K. Moortgat, Temperature dependence of the absorption cross sections of formaldehyde between 223 and $323 \mathrm{~K}$ in the wavelength range 225-375 nm, J. Geophys. Res. 105 (2000) 7089-7101. 